Tanjungpura Law Journal, Vol. 3, Issue 2, July 2019: 174 - 185

ISSN Print: 2541-0482 | ISSN Online: 2541-0490

Open Access at: http://jurnal.untan.ac.id/index.php/tli

Article Info

Submitted: 1 May 2019 | Reviewed: 10 May 2019 | Accepted: 20 June 2019

\title{
STUDI ATAS PASAL 63 UNDANG-UNDANG NOMOR 18 TAHUN 2017 TENTANG PERLINDUNGAN PEKERJA MIGRAN INDONESIA (PPMI)
}

\author{
Ria Wulandari ${ }^{1}$
}

\begin{abstract}
Law Number 18 Year 2017 on Indonesia Migrant Worker Protection has been ratified replace Law number 39 Year 2004 on Indonesian Labor Placement and protection because it is considered inappropriate with the development of needs Indonesia Migrant Worker Protection. Increasing practice of migrant worker especially internal sector migrant worker who often experience forced labor, victims of violence, arbitrariness, slavery even human trafficking and other treatment that violence human right mostly due to role service enterprise Indonesian labor role (PJTKI/PPMI) who commited many violations that causes Indonesian labor become a victim of a crime and inhuman treatment. Service enterprise role recognized in law number 39 of 2004. Law Number 18 Year 2017 as replace Law Number 39 Year 2004 expected to give more protection to Indonesian Migrant Worker although there has been a lot of progress in human right substansial one of which is recognition to informal sector migrant worker as a formal worker. However they are still required use service enterprice Indonesian Migrant Worker (article 63.1). This is contradictory with some articles in Law Number 18 Year 2017 and rises criminal act of trafficking in person.
\end{abstract}

Keywords : informal sector migrant worker; service enterprise role; trafficking in person

\begin{abstract}
Abstrak
Undang-Undang Nomor 18 Tahun 2017 tentang Perlindungan Pekerja Migran Indonesia (PPMI) telah disahkan menggantikan Undang-Undang Nomor 39 Tahun 2004 tentang Penempatan dan Perlindungan Tenaga Kerja Indonesia (PPTKI) di luar negeri karena dianggap sudah tidak sesuai dengan perkembangan kebutuhan perlindungan pekerja migran Indonesia. Meningkatnya praktik pekerja migrant khususnya pekerja migran sektor informal yang sering mengalami kerja paksa, korban kekerasan, kesewenang-wenangan, perbudakan bahkan perdagangan orang serta perlakuan lain yang melanggar hak asasi manusia sebagian besar dikarenakan peran Perusahaan Jasa Tenaga Kerja (PJTKI) atau Perusahaan Penempatan Tenaga Kerja Indonesia Swasta (PPTKIS) yang banyak melakukan pelanggaran yang menyebabkan pekerja migran menjadi korban tindak pidana dan perlakuan tidak manusiawi. Peran PJTKI ini diakui dalam UU Nomor 39 Tahun 2004. UU Nomor 18 Tahun 2017sebagai pengganti UU Nomor 39 Tahun 2004 diharapkan dapat lebih memberi perlindungan terhadap pekerja migran. Meski telah banyak kemajuan secara substansi pada pemenuhan hak asasi manusia salah satunya adalah pengakuan terhadap buruh migran yang bekerja sebagai pekerja rumah tangga sebagai pekerja formal, namun pekerja rumah tangga tetap diwajibkan menggunakan jasa Perusahaan Penempatan Pekerja Migran Indonesia (PPPMI) (pasal 63 ayat (1)). Hal ini bertentangan dengan beberapa pasal didalam tubuh UU Nomor 18 Tahun 2017 itu sendiri dan dengan aturan-aturan lain diluar UU tersebut. Selain itu ketentuan mengenai kewajiban menggunakan PPPMI bagi pekerja rumah tangga dinilai berpotensi menimbulkan tindak pidana perdagangan orang.
\end{abstract}

Kata Kunci : pekerja migran sektor informal; perdagangan orang; PJTKI/PPPMI

\footnotetext{
${ }^{1}$ Fakultas Hukum, Universitas Tanjungpura, Jln. Prof. Hadari Nawawi, Pontianak, 78124, Kalimantan Barat, Indonesia, email: ria.wulandari1979@gmail.com
} 


\section{Pendahuluan}

Jutaan orang telah melakukan migrasi untuk mendapakan pekerjaan. Situasi kerentanan seringkali dialami pekerja migran dan anggota keluarganya, antara lain karena ketidak beradaan mereka di negara asal dan karena kesulitan-kesulitan yang mungkin mereka hadapi yang timbul sebagai akibat dari keberadaan mereka di negara tempat mereka bekerja.

Majelis Umum Perserikatan Bangsa-Bangsa (PBB) telah mengeluarkan resolusi pada tanggal 18 Desember 1990 yang mengesahkan Konvensi internasional tentang Perlindungan Hak-Hak Seluruh Pekerja Migran Dan Anggota Keluarganya. Konvensi ini telah menetapkan prinsip-prinsip dasar mengenai perlakuan terhadap para pekerja migran dan anggota keluarganya dan mendorong tindakan tepat dalam rangka mencegah dan menghapuskan pergerakan dan perdagangan para pekerja migrant secara gelap, serta memastikan adanya perlindungan hak asasi manusia fundamental mereka. Indonesia telah meratifikasi konvensi ini dengan Undang-Undang Nomor 6 Tahun 2012. Ratifikasi terhadap konvensi dimaksudkan merefleksikan komitmen kuat pemerintah untuk pemajuan nilai-nilai hak asasi manusia termasuk didalamnya hak pekerja migran.

Undang Undang Dasar Negara Republik Indonesia mengamanatkan bahwa setiap orang berhak mendapatkan pekerjaan yang layak ${ }^{2}$ hal ini merupakan pencerminan

\footnotetext{
2 Pasal 27 ayat (2) Undang Undang Dasar Negara Republik Indonesia 1945.
}

dari hak asasi manusia yang wajib dijunjung tinggi, dihormati dan dijamin penegakannya.

Sepanjang Januari sampai Agustus 2017 Badan Nasional Penempatan dan Perlindungan Tenaga Kerja Indonesia (BNP2TKI) telah berhasil menempatkan sebanyak 148.285 orang pekerja migran ke seluruh negara tujuan penempatan. ${ }^{3}$

Penempatan pekerja migran ke luar negeri dibagi dalam dua (2) sektor yakni sektor formal dan informal. Jumlah pekerja migran yang bekerja di sektor formal sebanyak 83.943 orang. Sedangkan Tenaga Kerja Indonesia yang bekerja di sektor informal sebanyak 64.342. Malaysia merupakan Negara terbesar untuk penempatan pekerja migran ke luar negeri yaitu sebanyak 60.624 orang. ${ }^{4}$

Kebijakan negara-negara mengenai pekerjaan sektor formal dan informal berbeda-beda. Peraturan mengenai hubungan kerja di Arab Saudi misalnya, membedakan antara pekerja asing disektor formal dan informal. ${ }^{5}$ Berbeda dengan di Arab Saudi, untuk pekerja migran di Hongkong tidak dibedakan antara pekerja di sektor formal dan informal. ${ }^{6}$

Negara yang membedakan antara pekerja sektor formal dan informal memiliki kebijakan yang terpisah untuk mengatur kedua sektor ini, kebijakan untuk pekerja di sektor formal mengacu pada kebijakan

${ }^{3}$ www.BNP2TKI.go.id diakses tanggal 27 September 2017.

4 www.BNP2TKI.go.id

5 Sumiyati. 2013. "Perlindungan Hukum Bagi Pekerja Migran Indonesia di Luar Negeri Akibat Pemutusan Hubungan Kerja Sepihak", Jurnal Sigma-Mu, 5 (1), hlm. 55.

6 lbid. 
umum mengenai pekerja migran di negara tersebut, sementara untuk pekerja sektor informal meski telah ada pengaturan khusus biasanya dilakukan

lagi kesepakatan-kesepakatan tertentu antara pemberi kerja (majikan) dan penerima kerja (pekerja migran). Sementara Hongkong sebagai negara yang tidak membedakan antara pekerja sektor formal dan informal memiliki aturan ketenagakerjaan yang berlaku sama bagi kedua sektor yang tertuang dalam Buku Petunjuk Pelayanan di Hongkong (Your Guide to Services in Hongkong) yang isinya meliputi hak dan kewajiban bagi pekerja dan majikan, fasilitas-fasilitas serta bentuk-bentuk bantuan yang disediakan oleh pemerintah Hongkong bagi pekerja migran. ${ }^{7}$

Dalam praktiknya pekerja migran khususnya pekerja migran sektor informal sering mengalami kerja paksa, korban kekerasan, kesewenang-wenangan, perbudakan bahkan perdagangan manusia serta perlakuan lain yang melanggar hak asasi manusia. Perusahaan Jasa Tenaga Kerja (PJTKI) atau Perusahaan Penempatan Tenaga Kerja Indonesia Swasta (PPTKIS) telah banyak melakukan pelanggaran yang menyebabkan pekerja migran menjadi korban tindak pidana dan perlakuan tidak manusiawi.

Meningkatnya jumlah pekerja migran yang menjadi korban tindak pidana menyebabkan Undang-Undang Nomor 39 Tahun 2004 tentang Penempatan dan Perlindungan Tenaga Kerja Indonesia di Luar

\footnotetext{
7 lbid.
}

Negeri dianggap sudah tidak sesuai dengan perkembangan kebutuhan perlindungan pekerja migran Indonesia selain itu dianggap tidak sesuai dengan Konvensi Konvensi internasional tentang Perlindungan Hak-Hak Seluruh Pekerja Migran Dan Anggota Keluarganya Tahun 1990. Oleh karena itu pemerintah Indonesia telah membentuk Undang-Undang Nomor 18 Tahun 2017 tentang Perlindungan Pekerja Migran Indonesia (UU PPMI) menggantikan Undang-Undang Nomor 39 Tahun 2004.

Undang-Undang Nomor 18 Tahun 2017 tentang Perlindungan Pekerja Migran Indonesia (PPMI) dinilai banyak kemajuan baik secara proses maupun substansi yang berbasis pada pemenuhan hak asasi manusia salah satunya adalah pengakuan terhadap buruh migran yang bekerja sebagai pekerja rumah tangga sebagai pekerja formal. Penegasan ini tercantum dalam Pasal 4 ayat 1 yang berbunyi: "pekerja migran meliputi:

a. Pekerja migran Indonesia yang bekerja pada pemberi kerja berbadan hukum;

b. Pekerja migran Indonesia yang bekerja pada pemberi kerja perseorangan atau rumah tangga;

c. Pelaut awak kapal dan pelaut perikanan".

Undang-Undang Nomor 18 Tahun 2017 tentang Perlindungan Pekerja Migran Indonesia (PPMI) juga telah mampu memidana korporasi yang selama ini hanya dikenakan sanksi administrasi sehingga dapat mencegah dan mengurangi perdagangan manusia berkedok buruh migrant yang biasa dilakukan korporasi. Hal ini tercermin dalam Pasal 87 UU PPMI yang 
menegaskan jika tindak pidana dilakukan atas nama korporasi, tuntutan atau penjatuhan pidana dilakukan terhadap korporasi atau pengurusnya.

Namun meski telah memiliki beberapa kemajuan, ketentuan mengenai pekerja rumah tangga migran dianggap sama dengan Undang-Undang Nomor 39 Tahun 2004 dikarenakan pekerja rumah tangga migran masih tidak diperbolehkan bekerja secara perseorangan / mandiri. Ketentuan ini tercantum dalam Pasal 63 ayat 1 yang berbunyi: "pekerja migran perseorangan dapat bekerja ke luar negeri pada pemberi kerja berbadan hukum." Dari pasal tersebut dapat dikatakan bahwa pekerja rumah tangga tidak dapat dilakukan secara perseorangan / mandiri karena pekerja rumah tangga tidak bekerja pada pemberi kerja berbadan hukum dengan kata lain pekerja rumah tangga tetap berada dibawah perusahaan swasta. Pekerja rumah tangga migran diwajibkan mengunakan perusahaan penempatan pekerja migrant Indonesia berdasarkan skema Peraturan Pemerintah Nomor 5 Tahun 2013 tentang Tata Cara Penilaian dan Penetapan Mitra Usaha dan Pengguna Perseorangan. Alasan keberadaan pekerja rumah tangga migrant ditempatkan di bawah perusahaan swasta (PPPMI) karena sebagian besar pekerja rumah tangga tidak memiliki pendidikan dan keterampilan yang memadai, namun tetap saja Undang-Undang Nomor 18 Tahun 2017 dianggap belum sesuai dengan Konvensi internasional tentang Perlindungan Hak-Hak Seluruh Pekerja Migran Dan Anggota
Keluarganya Tahun 1990 selain itu Undang-Undang Nomor 18 Tahun 2017 disebut justru melanggengkan perdagangan orang.

Berdasarkan latar belakang tersebut diatas, permasalahan yang ada dapat dirumuskan sebagai berikut :

1. Apakah ketentuan Pasal 63 Undang-Undang Nomor 18 Tahun 2017 tentang Perlindungan Pekerja Migran Indonesia yang melarang pekerja rumah tangga migran bekerja secara perseorangan / mandiri memiliki kontradiksi hukum baik secara internal maupun eksternal?

2. Apakah ketentuan tentang Pekerja Rumah Tangga Migran yang di wajibkan menggunakan perusahaan swasta berpotensi menjadi perdagangan orang?

\section{Metode}

Penelitian ini menggunakan jenis penelitian hukum normatif. Penelitian hukum normatif atau kepustakaan tersebut mencakup penelitian terhadap asas-asas hukum, sistematika hukum, taraf sinkronisasi vertikal dan horizontal, perbandingan hukum dan sejarah hukum. ${ }^{8}$ Adapun penelitian ini adalah penelitian terhadap sinkronisasi hukum.

a. Pendekatan

Pendekatan yang digunakan dalam penelitian ini adalah pendekatan induktif yakni dimulai dari penelitian terhadap aturan hukum internasional yang

8 Zudan Arif Fakrulloh. 2007. Metode Penelitian Hukum. Pontianak: Bahan Kuliah Program Magister IImu Hukum, hIm. 9. 
kemudian diaplikasikan kedalam hukum nasional.

b. Sumber Data

Sumber data yang digunakan dalam penelitian ini adalah bahan hukum primer dan bahan hukum sekunder.

Bahan hukum primer yang dimaksud adalah peraturan perundang-undangan baik dalam tingkat internasional (Konvensi Internasional) dan tingkat nasional (Undang-Undang Nomor 18 Tahun 2017 dan Undang-Undang Nomor 21 Tahun 2007) serta peraturan-peraturan lain yang terkait.

Bahan hukum sekunder yang dimaksud adalah buku-buku hukum baik itu skripsi, tesis dan disertasi hukum, jurnal-jurnal hukum dan kasus-kasus hukum.

\section{Analisis dan Pembahasan}

Sebelum membahas masalah dalam penulisan ini akan dibahas terlebih dahulu mengenai berbagai pengertian antara lain pengertian Pekerja dan Pekerja Migran Indonesia.

Dewasa ini masalah migrasi telah sedemikian penting dan meluas dengan melibatkan jutaan manusia dan mempengaruhi sejumlah besar negara dalam komunitas internasional. Ber "Migrasi" berarti pindah ke tempat lain. Pergerakan orang-orang ini dapat terjadi didalam sebuah Negara - ini yang disebut sebagai "Migrasi Internal." Migrasi juga dapat terjadi ketika orang-orang berpindah dari sebuah negara ke Negara lain - disebut sebagai Migrasi Eksternal atau Emigrasi. ${ }^{9}$

Migrasi perburuhan adalah istilah yang digunakan untuk menggambarkan pergerakan/migrasi yang dilakukan orang dari sebuah tempat ke tempat lain, dengan tujuan bekerja atau menemukan pekerjaan. Ketika bermigrasi, mereka diklasifikasikan sebagai Pekerja Migran. Migrasi perburuhan mencakup berbagai jenis pekerja migran, mulai dari pekerja kontrak yang kurang terampil hingga semi dan sangat terampil. ${ }^{10}$

Dalam konteks migrasi perburuhan, negara-negara tempat para migran berasal disebut sebagai Negara Pengirim dan negara yang dituju disebut sebagai Negara Tujuan atau Negara Tuan Rumah. ${ }^{11}$

Organisasi Perburuhan Internasional (International Labour Organization / ILO) mendefinisikan seorang Pekerja Migran sebagai seseorang yang bermigrasi dari satu Negara ke Negara lain, dengan sebuah gambaran bahwa orang tersebut akan diperkerjakan oleh seseorang yang bukan dirinya sendiri, termasuk siapapun yang biasanya diakui sebagai seorang migran untuk bekerja. ${ }^{12}$

Banyak penduduk Indonesia yang tidak mendapat kesempatan bekerja didalam negeri sehingga harus bermigrasi ke luar negeri (migrasi internasional) untuk bekerja. Beberapa teori telah dirujuk untuk menjawab faktor-faktor terjadinya migrasi internasional

\footnotetext{
9 Perlindungan dan Pencegahan Untuk Pekerja Migran Indonesia, Penghapusan Kerja Paksa dan Perdagangan Manusia Pada Pekerja Migran Indonesia, www.ilo.org/iigiakarta, hlm. 3.

10 lbid.

11 lbid.

12 Ibid, hlm. 4.
} 
diantaranya teori neoclassical economy yang mengemukakan bahwa, dalam konteks makro, migrasi tenaga kerja internasional terjadi karena adanya perbedaan kesempatan kerja serta gaji/upah antara negara pengirim dan penerima. ${ }^{13}$ Namun tidak semua migrasi tingkat internasional disebabkan perbedaan kesempatan kerja serta gaji/upah semata, karena dewasa ini sebagian orang melakukan migrasi karena memang berkeinginan untuk bekerja di negara tertentu dan biasanya orang-orang tersebut telah memiliki keterampilan khusus atau seseorang dibidangnya.

Undang-Undang Nomor 39 Tahun 2004 memberi istilah Tenaga Kerja Indonesia (TKI) bagi warga negara Indonesia yang bekerja di luar negeri dalam jangka waktu tertentu. Tenaga Kerja Indonesia (TKI) terbagi menjadi 2 (dua) sektor yaitu sektor formal dan sektor informal. TKI sektor formal adalah tenaga kerja Indonesia yang bekerja di perusahaan negara atau swasta yang berada di luar negara Indonesia contohnya hotel, kapal pesiar, pengeboran dan lain-lain. TKI sektor informal adalah tenaga kerja Indonesia yang bekerja pada perseorangan, contohnya Penata Laksana rumah Tangga (PLRT), pengasuh anak dan lansia (baby sitter), perawat, tukang kebun, sopir dan lain-lain. TKI yang bekerja di sektor informal umumnya adalah perempuan. Meningkatnya jumlah pekerjaan di sektor informal menyebabkan jumlah perempuan migran

\footnotetext{
13 Mita Noveria. 2017. "Migrasi Berulang Tenaga Kerja Migran Internasional : Kasus Pekerja Migran Asal Desa Sukorejo, Wetan, Kabupaten Tulungagung", Jurnal Kependudukan Indonesia, 12 (1), hlm. 28.
}

meningkat. Saat ini semakin banyak perempuan yang bekerja di luar negeri sebagai pekerja rumah tangga di Negara-negara timur-tengah khususnya Arab Saudi dan kawasan asia pasifik terutama Negara Malaysia, Hongkong, Taiwan dan Singapura. Terjadinya pergeseran migran ke luar negeri dari laki-laki kepada perempuan dikenal dengan istilah Feminisme Migrasi. ${ }^{14}$ TKI perempuan yang umumnya bekerja sebagai PLRT dan (baby sitter) merupakan bidang pekerjaan terbesar yang dikirim oleh pemerintah Indonesia. Peningkatan migrasi tenaga kerja perempuan berkaitan dengan tingginya permintaan PLRT dan baby sitter di negara tujuan. Sementara itu, migrasi tenaga kerja laki-laki lebih berkaitan dengan respon terhadap kebutuhan tenaga kerja demi proses industrialisasi. ${ }^{15}$

Istilah Tenaga Kerja Indonesia (TKI) kemudian diganti oleh Undang-Undang Nomor 18 Tahun 2017 tentang Perlindungan Pekerja Migran Indonesia menjadi Pekerja Migran Indonesia (PMI). Yang dimaksud dengan Pekerja Migran Indonesia Pasal 1 angka 4 yaitu setiap warga negara Indonesia yang akan, sedang atau telah melakukan pekerjaan dengan menerima upah di luar wilayah Republik Indonesia. Hal ini sejalan dengan definisi yang diberikan oleh Konvensi Internasional tentang Perlindungan Hak-Hak Seluruh Pekerja Migran Dan Anggota Keluarganya yang memberi definisi tentang

\footnotetext{
14 Muhamad Zid. 2012. Migrasi Internasional Perempuan, Penguasaan dan Kesetaraan Gender. Bogor: Sekolah Pasca Sarjana IPB, hlm. 11.

15 Sukamdi. 2007. "Memahami Migrasi Pekerja Indonesia Ke Luar Negeri", Jurnal Populasi, 18 (2), 2007, hlm. 121.
} 
Pekerja Migran yaitu mengacu pada seseorang yang akan, tengah atau telah melakukan aktifitas yang dibayar disuatu negara dimana ia bukan merupakan warga negara. ${ }^{16}$

\section{A. Ketentuan Pasal 63 ayat 1 Undang-Undang No 18 Tahun 2017 Berkontradiksi secara internal dan eksternal dengan peraturan lain.}

Undang-Undang Nomor 18 Tahun 2017 dianggap berbeda dengan undang-undang sebelumnya, salah-satunya mengenai mekanisme melakukan perjanjian kerja secara mandiri. Jika dalam undang-undang Nomor 39 Tahun 2004 semua pekerja baik sektor formal maupun informal diwajibkan menggunakan jasa PJTKI, maka dalam Undang-Undang Nomor 18 Tahun 2017 memberi kesempatan bagi pekerja melakukan perjanjian kerja tanpa

16 Pasal 3 Konvensi Perlindungan Hak-Hak Seluruh Pekerja Migran Dan Anggota Keluarganya : "konvensi ini tidak boleh berlaku bagi :

a. Orang-orang yang dikirim atau diperkerjakan oleh organisasi dan badan-badan internasional, atau oleh suatu Negara diluar wilayahnya untuk menjalankan tugas resmi, yang kedatangan dan statusnya diatur oleh hukum internasional umum atau oleh perjanjian internasional atau konvensi khusus:

b. Orang-orang yang dikirim atau diperkerjakan oleh suatu Negara atau atas nama Negara diluar wilayahnya yang berpartisipasi dalam program pembangunan dan program kerjasama lain, yang kedatangan dan statusnya diatur oleh perjanjian dengan negara tujuan kerja, dan yang sesuai dngan perjanjian tersebut, tidak dianggap sebagai pekerja migrant;

c. Orang-orang yang bertempat tinggal di Negara yang berbeda dengan Negara asalnya sebagai penanam modal;

d. Pengungsi atau orang tanpa kearganegaraan, kecuali ketentuan tentang hal ini ditetapkan dalam ketentuan hukum nasional, atau dalam instrument internasional yang berlaku bagi Negara pihak tersebut;

e. Pelajar dan peserta pelatihan;

f. Pelaut dan pekerja pada suatu instalasi lepas pantai yang belum memperoleh ijin tinggal dan melakukan aktifitas yang dibayar di Negara tujuan kerja. melalui perusahaan penempatan (Pasal 1 ayat 4). Akan tetapi terdapat pasal lain dalam undang-undang ini yang menyebutkan bahwa hanya pekerja yang bekerja pada perusahaan berbadan hukum saja yang dapat melakukan perjanjian kerja secara mandiri. Ini artinya tidak semua pekerja migran dapat melakukan perjanjian kerja secara mandiri sebagaimana disebut dalam Pasal 1 ayat 4, Pekerja migran yang bekerja pada perseorangan tetap harus menggunakan jasa perusahaan penempatan swasta. Padahal berdasarkan data dari Laporan Pekerja Global Indonesia: Antara Peluang dan Resiko yang dirilis oleh World Bank menyebutkan Pekerja Migran Indonesia sekitar 32\% bekerja sebagai pembantu rumah tangga atau pengasuh anak, pekerja pertanian 19\%, pekerja konstruksi $18 \%$, pekerja pabrik $8 \%$, perawat lansia $6 \%$, pekerja toko/restoran/hotel, supir $2 \%$ dan pekerja kapal pesiar. Dari data diatas bisa kita katakan sekitar 32\% Pekerja Migran Indonesia harus menggunakan jasa perusahaan penempatan swasta. ${ }^{17}$

Kontradiksi internal antara Pasal 1 ayat 4 dan Pasal 63 ayat 1 juga mengakibatkan benturan dengan asas kesetaraan dan keadilan gender yang dianut dalam undang-undang ini (Pasal 2). Hal ini dikarenakan orang yang bekerja pada perseorangan yang tidak berbadan hukum dari data yang disebutkan diatas didominasi oleh perempuan yakni $32 \%$. Hal ini membuat

\footnotetext{
17 Amanda Kusumawardhani. "Survey World Bank;9 Juta Pekerja Indonesia di Luar Negeri", https://ekonomi.bisnis.com, diakses 28 November 2019.
} 
perempuan yang bekerja pada sektor domestik tersebut tidak dapat secara mandiri melakukan perjanjian kerja sebagaimana pekerja di sektor perkebunan dan industrial yang biasanya didominasi laki-laki. Pembedaan yang dibuat dalam Pasal 63 ayat (1) dapat disebut sebagai diskriminasi, lebih spesifik diskriminasi gender.

Diskriminasi gender terhadap pekerja migran sebetulnya telah terjadi secara global Contohnya Employment Act 1995 yang merupakan Undang-Undang Ketenagakerjaan Malaysia tentang pengaturan hak-hak pekerja migran disektor domestik terbatas pada masalah penyelesaian kontrak bukan perlindungan. ${ }^{18}$

Dalam memerangi segala bentuk diskriminasi terhadap pekerja migran, Konvensi Perlindungan Hak-Hak Seluruh Pekerja Migran dan Anggota Keluarganya dalam Pasal 1 telah melarang pembedaan atas dasar apapun terhadap pekerja migran seperti jenis kelamin, ras, warna kulit, bahsa, agama, kepercayaan, kebangsaan, asal-usul, etnis, kewarganegaraan, usia, kedudukan ekonomi, kekayaan, status perkawinan, status kelahiran, pendapat politik dan lain-lain.

Dalam tataran nasional, Pasal 28 ayat I UUD 1945 dapat dilihat sebagai upaya pemerintah Republik Indonesia untuk menghapus segala bentuk diskriminasi atas dasar apapun dan wajib memberi perlindungan atas perlakuan yang bersifat

18 Ana Sabhana Azmy. 2012. Negara dan Buruh Migran Indonesia; Kebijakan Perlindungan Buruh Migran Perempuan Indonesia Masa Pemerintahan Susilo Banbang Yudhoyono (SBY) 2004-2010. Jakarta: Yayasan Pustaka Obor Indonesia, hlm. diskriminatif. Pasal 63 ayat 1 Undang-Undang Nomor 18 Tahun 2017 yang membeda-bedakan mekanisme perjanjian kerja justru bertentangan dengan semangat non diskriminasi sebagaiman diamanatkan dalam UUD 1945 dan Konvensi Perlindungan Hak-Hak Seluruh Pekerja Migran dan Anggota Keluarganya.

Kita memaklumi pemikiran pemerintah yang mengharuskan pekerja migran yang bekerja pada perseorangan tidak berbadan hukum yang biasanya sebagai Penata Laksana Rumah Tangga dianggap tidak memiliki keterampilan yang cukup dan jenjang pendidikan yang rendah membuat mereka tidak bisa melakukan perjanjian kerja secara mandiri. Namun alih-alih membuat aturan yang berbeda antara pekerja satu dan lainnya yang justru bertentangan dengan kesetaraan dan keadilan gender, pemerintah seharusnya lebih meningkatkan keahlian pekerja migran rumah tangga sehingga memiliki posisi tawar yang lebih baik dinegara tujuan, membuat standarisasi perjanjian kerja yang berlaku di kedua negara sehingga pekerja rumah tangga telah merngetahui dan mempelajari hak dan kewajibannya sejak ditanah air, melakukan pendampingan dan pengawasan pada saat pembuatan perjanjian kerja, memastikan perjanjian kerja dibuat dalam dua Bahasa. Dengan keterampilan dan pengetahuan yang cukup pekerja migran akan mampu melindungi dirinya di negara tujuan. 
B. Ketentuan tentang Pekerja Rumah Tangga Migran yang di wajibkan menggunakan perusahaan penempatan swasta berpotensi menjadi perdagangan orang

Majelis Umum Perserikatan Bangsa-Bangsa telah mengesahkan Transnational Organized Crime (TOC) atau juga disebut Konvensi Palermo pada tanggal 15 November 2000 dan mulai diberlakukan pada tanggal 15 November 2003. Konvensi Palermo bertujuan untuk mencegah, menekan dan menghukum perdagangan atas manusia khususnya kaum perempuan dan anak-anak.

Indonesia telah meratifikasi Konvensi Transnational Organized Crime (TOC) pada tanggal 19 April 2007 dan mengesahkannya serta mengundangkannya ke dalam Lembar Negara RI Tahun 2007 No 58, Tambahan Lembar Negara RI Nomor 4720, Undang-Undang Nomor 21 Tahun 2007 tentang Pemberantasan Tindak Pidana Perdagangan Orang (TPTPPO).

Unsur-unsur tindak pidana perdagangan orang sebagaimana tercantum dalam Pasal 2 ayat 1 Undang-Undang Nomor 21 Tahun 2007 tentang Pemberantasan Tindak Pidana Perdagangan Orang (TPTPPO) meliputi 4 unsur: ${ }^{19}$

1. Pelaku, Unsur pelaku meliputi orang perseorangan, korporasi, kelompok terorganisasi dan penyelenggara Negara.

2. Proses/Tindakan, Unsur proses / tindakan merupakan urutan pelaksanaan atau kejadian baik terjadi secara alami atau didesain

19 Paul Sinlaeloe. 2017. Tindak Pidana Perdagangan Orang. Jawa Timur: Setara Press, hIm. 4. meliputi perekrutan, pengangkutan, penampungan, pengiriman, pemindahan atau penerimaan seseorang.

3. Cara/Modus, Unsur cara / modus yaitu bentuk perbuatan / tindakan tertentu yang dilakukan untuk menjamin proses dapat terlaksana yang meliputi: ancaman, kekerasan, penggunaan kekerasan, penculikan, penyekapan, pemalsuan, penipuan, penyalahgunaan kekuasaan atau posisi rentan, penjeratan utang atau memberi bayaran atau manfaat walaupun memperoleh persetujuan dari orang yang memegang kendali atas orang lain.

4. Tujuan /Akibat, Unsur tujuan / akibat yaitu sesuatu yang nantinya akan tercapai dan atau terwujud sebagai akibat dari tindakan pelaku tindak pidana perdagangan orang yang meliputi eksploitasi orang atau mengakibatkan orang tereksploitasi sebagaimana diamantkan dalam Pasal 1 angka 1, Pasal 2 ayat 1 dan Pasal 2 ayat 2 Undang-Undang Tindak Pidana Perdagangan Orang.

Undang-Undang Nomor 39 Tahun 2004 mengenai Penempatan Tenaga Kerja Indonesia mengatur bahwa perusahaan jasa tenaga kerja Indonesia (PJTKI) dapat melakukan tindakan perekrutan, penampungan dan pengiriman tenaga kerja Indonesia ke Negara tujuan. Dalam proses perekrutan biasanya perusahaan jasa tenaga kerja Indonesia (PJTKI) telah melakukan pemalsuan dokumen dan identitas. Setelah para tenaga kerja Indonesia tiba di Negara tujuan banyak dari mereka dieksploitasi, ditempatkan di lokalisasi pelacuran bahkan ada yang meninggal tanpa memiliki beberapa organ tubuhnya. Peristiwa diatas telah memenuhi unsur-unsur perdagangan orang 
mulai dari unsur pelaku, unsur proses / tindakan, unsur cara / modus dan unsur tujuan/ akibat. Meski Undang-Undang Nomor 34 Tahun 2004 telah diganti, namun Undang-Undang Nomor 18 Tahun 2017 tentang Perlindungan Pekerja Migran Indonesia tetap mengacu pada Undang-Undang Nomor 39 Tahun 2004 khusus mengenai pekerja rumah tangga yang di wajibkan menggunakan jasa perusahaan penempatan pekerja migran Indonesia. Meskipun Undang-Undang Nomor 18 Tahun 2017 mengamanatkan bahwa yang melakukan perekrutan dan pembinaan adalah pemerintah daerah namun tidak bisa dipungkiri bahwa terdapat oknum-oknum pemerintah daerah sebagai penyelenggara negara dalam kasus-kasus terdahulu turut berperan atas terjadinya tindak pidana perdagangan orang.

\section{Penutup}

Undang-Undang Nomor 18 Tahun 2017 Tentang Perlindungan Pekerja Migran Indonesia (UU PPMI) yang telah disahkan pada tangal 25 Oktober 2017 merupakan pengganti dari dari UU 39 Tahun 2004 tentang Penempatan dan Perlindungan Tenaga Kerja Indonesia (PPTKILN). Salah-satu perubahan yang cukup signifikan adalah dimasukkannya ke dalam konsideran UU PPMI 2017 Konvensi Perlindungan Pekerja Migran dan Anggota Keluarganya Tahun 1990 yang telah diratifikasi oleh pemerintah Indonesia melalui Undang-Undang Nomor 6 Tahun 2012. Sebagai negara peratifikasi konvensi
Indonesia wajib mengharmonisasi dan mengimplementasikan artikel-artikel dalam Konvensi Pekerja Migran dan Anggota Keluarganya Tahun 1990. Pasal yang dianggap berkontradiksi yaitu Pasal 63 ayat (1), memiliki maksud yang bertentangan dengan Pasal 4 UU PPMI itu sendiri.

Kontradiksi eksternal yaitu terhadap Pasal 28i ayat (2) Undang-Undang Dasar Negara Republik Indonesia mengenai larangan diskriminasi dan Konvensi Perlindungan Hak-Hak Seluruh Pekerja Migran dan Anggota Keluarganya.

ketentuan tentang Pekerja Rumah

Tangga Migran yang di wajibkan menggunakan perusahaan swasta berpotensi menjadi perdagangan orang. Empat unsur Tindak Pidana Perdagangan Orang meliputi adanya pelaku baik orang atau korporasi (bisa oleh oknum penyeleggara negara atau perusahaan penempatan pekerja migran), adanya proses (mulai perekrutan hingga pegiriman), cara/modus (pemalsuan dokumen), hingga akibat (mengakibatkan orang tereksploitasi). Terpenuhinya empat unsur diatas maka suatu perbuatan dapat disebut sebagai Tindak Pidana Perdagangan Orang. Undang-Undang Nomor 18 Tahun 2017 yang mengharuskan pekerja migran rumah tangga menggunakan perusahaan penempatan berarti membuka celah terjadinya tindak pidana perdagangan orang meskipun tindakan perekrutan dan pembinaan dilakukan oleh pemerintah daerah tetapi kasus terdahulu membuktikan adanya peran 
penyelenggara dalam terjadinya tindak pidana perdagangan orang.

\section{Bibliografi}

Buku:

Ana Sabhana Azmy. 2012. Negara dan Buruh Migran Indonesia; Kebijakan Perlindungan Buruh Migran Perempuan Indonesia Masa Pemerintahan Susilo Bambang Yudhoyono (SBY) 2004-2010. Jakarta: Yayasan Pustaka Obor Indonesia.

Muhamad Zid. 2012. Migrasi Internasional Perempuan, Penguasaan dan Kesetaraan Gender. Bogor: Sekolah Pasca Sarjana IPB.

Paul Sinlaeloe. 2017. Tindak Pidana Perdagangan Orang. Jawa Timur: Setara Press.

Zudan Arif Fakrulloh. 2007. Metoda Penelitian Hukum. Pontianak: Bahan Kuliah Program Magister IImu Hukum.

Jurnal:

Mita Noveria. 2017. "Migrasi Berulang Tenaga Kerja Migran Internasional : Kasus Pekerja Migran Asal Desa Sukorejo, Wetan, Kabupaten Tulungagung", Jurnal Kependudukan Indonesia, 12 (1).

Sukamdi. 2007. "Memahami Migrasi Pekerja Indonesia Ke Luar Negeri", Jurnal Populasi, 18 (2).

Sumiyati. 2013. "Perlindungan Hukum Bagi Pekerja Migran Indonesia di Luar Negeri Akibat Pemutusan Hubungan
Kerja Sepihak", Jurnal Sigma-Mu, 5 (1).

Tika Santika, Nia Hoerniasih, Een Nurhasanah. "Pemberdayaan Perempuan Bagi Tenaga Kerja Wanita (TKW) Di Desa Gempol KKabupaten Karawang, Lembaga Penelitian Dan Pengabdian Pada Masyarakat", Jurnal Majalah IImiah Solusi Unsika, 10 (22).

\section{Peraturan Perundang-Undangan:}

Undang Undang Dasar Negara Republik Indonesia 1945

Undang-Undang Nomor 39 Tahun 2004 Tentang Penempatan dan Perlindungan TKI (Lembaran Negara Republik Indonesia Tahun 2004 Nomor 133)

Undang-Undang Nomor 21 Tahun 2007 Tentang Pemberantasan Tindak Pidana Perdagangan Orang (Lembaran Negara Republik Indonesia Tahun 2007 Nomor 58, Tambahan Lembaran Negara Republik Indonesia Nomor 4720)

Undang-Undang Nomor 18 Tahun 2017 Tentang Perlindungan Pekerja Migran Indonesia (Lembaran Negara Republik Indonesia Tahun 2017 Nomor 242, Tambahan Lembaran Negara Republik Indonesia Nomor 6141)

\section{Internet:}

Amanda Kusumawardhani. "Survey World Bank;9 Juta Pekerja Indonesia di Luar Negeri”, https://ekonomi.bisnis.com, diakses tanggal 28 Januari 2019. 
Perlindungan dan Pencegahan Untuk Pekerja Migran Indonesia, Penghapusan Kerja Paksa dan Perdagangan Manusia Pada Pekerja Migran Indonesia, www.ilo.org/jogjakarta.

www.bnp2tki.go.id, diakses tanggal 27 september 2017. 